\title{
INTRAORAL SHWANNOMA MIMICKING MUCOCELE: A CASE REPORT
}

\author{
Shobha H. B ${ }^{1}$, Anusha Kumari², Sowmya S. V³
}

\section{HOW TO CITE THIS ARTICLE:}

Shobha H. B, Anusha Kumari, Sowmya S. V. "Intraoral Shwannoma Mimicking Mucocele: A Case Report". Journal of Evolution of Medical and Dental Sciences 2015; Vol. 4, Issue 01, January 01; Page: 127-129,

DOI: $10.14260 /$ jemds/2015/20

INTRODUCTION: Schwannomas are benign, slow growing nerve sheath tumours arising from Schwann cells. ${ }^{1}$ These are tumours that we come across quite often in our day to day practice. Approximately 25-40\% of schwannomas occur in the head and neck region.2,3,4,5 However, schwannomas that present in the oral cavity are relatively rare, constituting around $1 \%$ of all described cases in the head and neck region.2,3,4 Here, we present a case of an intraoral schwannoma, in a thirteen year old boy.

CASE HISTORY: A thirteen year old boy presented with a swelling on the undersurface of the tongue. Examination revealed $1 \times 1 \mathrm{~cm}$ swelling with smooth external surface which was cystic in consistency.

Excision biopsy of the lesion revealed $1.7 \times 1 \times 0.8 \mathrm{~cm}$ encapsulated mass with smooth surface and glistening brown, soft to firm cut-surface.

Microscopy showed an encapsulated tumour covered by a stratified squamous epithelium and skeletal muscle, composed of interlacing fascicles of spindle shaped cells with elongated wavy nuclei, moderate amount of eosinophilic cytoplasm and indistinct cell borders. Numerous Verocay bodies were present. On immunohistochemistry, the cells were strongly positive for S- 100 .

DISCUSSION: Schwannomas are the most common benign nerve sheath tumours that arise from Schwann cells. Though they can occur at any site, they are more commonly seen in the head and neck region and in the extremities where they arise from small to medium sized nerves. One third of the extracranial schwannomas occur in the head and neck region and $1 \%$ of the head and neck schwannomas occur in the oral cavity.6,7,8 In the oral cavity, the tongue is the most common preferred site followed by the palate and buccal mucosa. ${ }^{3,6,9}$ They are usually solitary, encapsulated tumours composed of cellular Antoni A areas, hypocellular Antoni B areas and Verocay bodies where rows of nuclei line up in a nuclear palisade. In our case the lesion was composed mainly of Verocay bodies.

Schwannomas occur in all age groups and are mostly seen in people between second to fifth decade. Intra oral schwannomas have been described in people between second to third decade. ${ }^{10}$

Given that intra oral schwannomas are a very rare occurrence, it is quite often misdiagnosed as a mucocele, ranula, traumatic fibroma or a fibroepithelial polyp. Our case presented as an intraoral swelling with cystic consistency and was clinically diagnosed as a mucocele.

Histopathology followed by immunohistochemistry confirmed the diagnosis of schwannoma.

\section{REFERENCES:}

1. Karaca CT, Habesoglu TE, Naiboglu B, Habesoglu M, Oysu C, Egeli E, et al. Schwannoma of the tongue in a child. Am J Otolaryngol. 2010 Feb; 31 (1): 46-8.

2. Grabowski L. [A rare case of schwannoma of the tongue]. Otolaryngol Pol. 2008; 62 (2): 191-4. 


\section{CASE REPORT}

3. Martins MD, Anunciato de Jesus L, Fernandes KPS, Bussadori SK, Taghloubi SA, Martins MAT. Intra-oral schwannoma: case report and literature review. Indian J Dent Res. 2009 Mar; 20 (1): 121-5.

4. Rabbels J, Scheer M, Heibel H, Wickenhauser C, Kübler AC. [Neurinoma of the hard palate in an 11-year-old girl. Case report]. Mund Kiefer Gesichtschir. 2005 Nov; 9 (6): 400-3.

5. Arda HN, Akdogan O, Arda N, Sarikaya Y. An unusual site for an intraoral schwannoma: A case report. Am J Otolaryngol. 2003 Oct; 24 (5): 348-50.

6. Huang C-M, Leu Y-S. Schwannoma of the posterior pharyngeal wall. J Laryngol Otol. 2002 Sep; 116 (9): 740-1.

7. Lukšić I, Müller D, Virag M, Manojlović S, Ostović KT. Schwannoma of the tongue in a child. J Craniomaxillofac Surg. 2011 Sep; 39 (6): 441-4.

8. Catalfamo L, Lombardo G, Nava C, Familiari E, Petrocelli M, Iudicello V, et al. Tongue schwannoma: clinicopathological findings. J Craniofac Surg. 2011 May; 22 (3): 1158-61.

9. Isildak H, Yilmaz M, Ibrahimov M, Aslan M, Karaman E, Enver O. Schwannoma of the hard palate. J Craniofac Surg. 2010 Jan; 21 (1): 276-8.

10. Nakasato T, Kamada Y, Ehara S, Miura Y. Multilobular neurilemmoma of the tongue in a child. AJNR Am J Neuroradiol. 2005 Feb; 26 (2): 421-3.

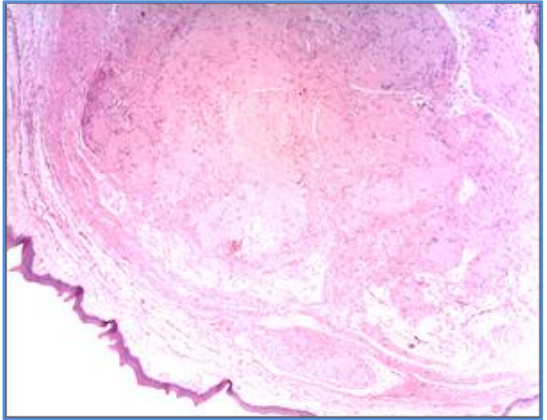

Fig. 1: Low power view showing an encapsulated tumour covered by stratified squamous epithelium. H\&E 50x

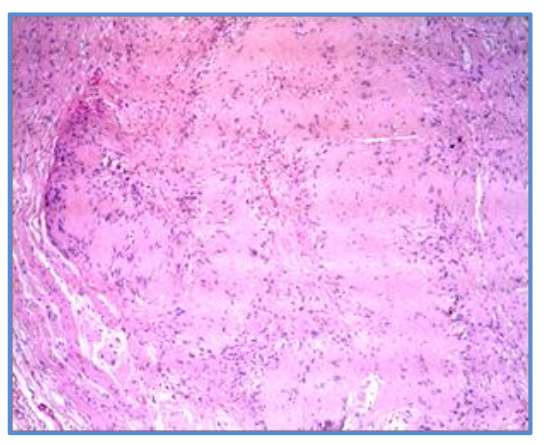

Fig. 2: The tumour is composed of predominantly Verocay bodies with nuclear palisading. H\&E $100 \mathrm{X}$

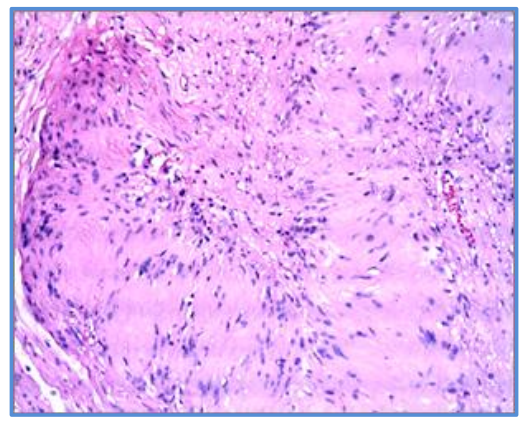

Fig. 3: High power view of the Verocay bodies. H\&E 200X

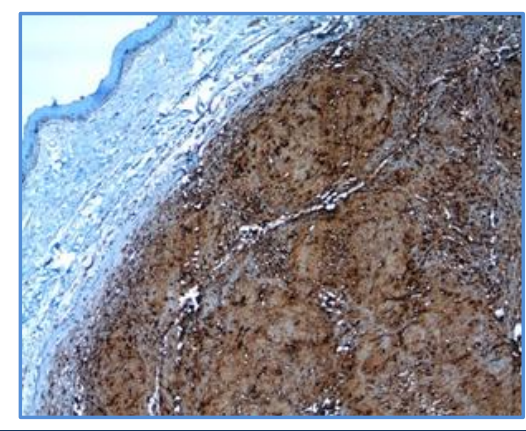

Fig. 4: The tumour cells show a strong positive reaction for $S-100$ antibody. S-100 50x 


\section{AUTHORS:}

1. Shobha H. B.

2. Anusha Kumari

3. Sowmya S. V.

\section{PARTICULARS OF CONTRIBUTORS:}

1. Final Year Post Graduate Student, Department of General Pathology, Christian Medical College, Vellore.

2. Assistant Professor, Department of General Pathology, Christian Medical College, Vellore.

3. Assistant Professor, Department of Dental Sciences, Christian Medical College, Vellore.

\section{NAME ADDRESS EMAIL ID OF THE CORRESPONDING AUTHOR:}

Dr. Shobha H. B, $3^{\text {rd }} \mathrm{F}$ Cross, $3^{\text {rd }}$ Stage, $2^{\text {nd }}$ Block, $4^{\text {th }}$ Main, Basaveshwara Nagar, Bangalore-79.

E-mail: drshobhahb@yahoo.co.in

Date of Submission: 02/09/2014.

Date of Peer Review: 14/10/2014.

Date of Acceptance: 23/12/2014.

Date of Publishing: 01/01/2015. 